\title{
Effect of water regime and salinity on artichoke yield
}

\author{
Francesca Boari, ${ }^{1}$ Bernardo Pace, ${ }^{1}$ Mladen Todorović, ${ }^{2}$ Egidio De Palma, ${ }^{1}$ Vito Cantore ${ }^{1}$ \\ ${ }^{1}$ Consiglio Nazionale delle Ricerche (CNR) - Istituto di Scienze delle Produzioni Alimentari, Bari; \\ ${ }^{2}$ CIHEAM - Istituto Agronomico Mediterraneo di Bari, Valenzano (BA), Italy
}

\begin{abstract}
This work focuses on the effects of different salinity and water inputs on the yield of artichoke Violetto di Provenza. Two years of experimental works had been carried out in a site in Southern Italy characterized by semi-arid climate and deep loam soil. Three salinity levels of irrigation water (S0, S1 and S2) with electrical conductivity (ECw) of $0.5,5$ and $10 \mathrm{dS} \mathrm{m}^{-1}$, respectively, were combined with three water regimes (W1, W2 and W3) corresponding in that order to 2040 and $60 \%$ of available water depletion.

The overall results of the salinity tolerance are in agreement with those from the literature. However, an higher tolerance to salinity was demonstrated when crop was watered more frequently (at $20 \%$ of available water depletion) and a lower one when crop watering was performed less frequently (at $60 \%$ of available water depletion). The increase of salinity level reduced marketable yield (from 12.9 to 8.8 $\mathrm{Mg} \mathrm{ha}^{-1}$ ), total heads (from 125,100 to $94,700 \mathrm{n} \mathrm{ha}^{-1}$ ) and heads mean weight (from 99.9 to $94.6 \mathrm{~g}$ ), while increased heads dry matter (from 161.8 to $193.6 \mathrm{~g} \mathrm{~kg}^{-1} \mathrm{fw}$ ) and reduced edible parte percentage of heads (from 35.2 to $33.2 \%$ ). Watering regimes, as average of the salinity levels, affected total heads marketable yield (115,350 $\mathrm{n} \mathrm{ha}^{-1}$ and $11.4 \mathrm{Mg}$ $\mathrm{ha}^{-1}$ for W1 and W2, 105,900 $\mathrm{n} \mathrm{ha} \mathrm{h}^{-1}$ and $10 \mathrm{Mg} \mathrm{ha}^{-1}$ for W3). In addition, different watering regimes affected the secondary heads yield for which it was reduced by $3 \%$ of mean weight.
\end{abstract}

The effect of different watering regimes changed with various salin-

Correspondence: Dr. Bernardo Pace, Consiglio Nazionale delle Ricerche (CNR) - Istituto di Scienze delle Produzioni Alimentari, via Amendola 122/0, 70126 Bari, Italy.

Tel. +39.080.5929333 - Fax: +39.080 .5929373 .

E-mail: bernardo.pace@ispa.cnr.it

Key words: brackish water, Cýnara cardunculus, irrigation regime, yield.

Acknowledgements: this research was funded by CLIMESCO Evolution of cropping systems as affected by climate change project, contract n. 285, 20/02/2006 (Ministry for Education, University and Research).

Received for publication: 5 April 2011.

Accepted for publication: 16 December 2011.

CCopyright F. Boari et al., 2012

Licensee PAGEPress, Italy

Italian Journal of Agronomy 2012; 7:e9

doi:10.4081/ija.2012.e9

This article is distributed under the terms of the Creative Commons Attribution Noncommercial License (by-nc 3.0) which permits any noncommercial use, distribution, and reproduction in any medium, provided the original author(s) and source are credited. ity levels. In condition of moderate salinity (S1), maximum water depletion fraction to preserve heads number and weight yield was 40 and $20 \%$ of total soil available water, respectively. However, with high salinity (S2), maximum water depletion fraction to keep unchanged heads number and weight yield was $20 \%$ for both.

The level of soil salinity at beginning of the crop cycle favoured the incidence of head atrophy in the main heads produced in the second year.

\section{Introduction}

Salinization of land has threatened civilizations in ancient and modern times (Rengasamy, 2006). In southern Mesopotamia and in several parts of the Tigris-Euphrates valley, soil salinization destroyed the ancient societies that had successfully thrived for several centuries (Jacobsen and Adams, 1958; Hillel, 2005). In modern times, saltaffected soils are naturally present in more than 100 countries of the world where many regions are also affected by irrigation-induced salinization. According to a recent report published by FAO (MartinezBeltran and Manzur, 2005), the total global area of salt-affected soils including saline and sodic soils accounts to 831 million hectares extending over all the continents.

In the Mediterranean region, many coastal areas are subjected to salty water intrusion in the aquifer systems which occurred because of the rate of abstraction and recharge of groundwater quantity are not in balance (Rapti-Caputo, 2010), as it happens also in Apulia region (Cotecchia and Polemio, 1997; Polemio and Limoni, 2001). As RaptiCaputo (2010) described, the principal causes of the acceleration of the salt water intrusion processes in the coastal aquifer systems include: i) the relative sea level rise; ii) coastal erosion phenomena; iii) the variation of the river flow (decrease of the alimentation of the aquifer system along the hydrographical network); iv) human activities (groundwater over-exploration); and v) climate changes affecting the hydrological balance (e.g.. decrease of precipitation and/or increase of evapotranspiration).

Soil salinization is the accumulation of water-soluble salts in the soil to a level that affects agricultural production, environmental health, and economic welfare (Rengasamy, 2006).

In many irrigated areas, dwindling supplies of quality water for irrigation and increasing demand from other users are forcing farmers to use saline irrigation waters (Rhoades, 1987; Rhoades et al., 1992; Shani and Dudley, 2001). However, the use of saline water for irrigation inhibits plant growth by an osmotic effect, which reduces the ability of the plant to take up water and by ion excess, which affects the plant cells (Munns, 2002, 2005). Moreover, soil salinity induces reduced plant growth due to specific ion toxicities (e.g., $\mathrm{Na}^{+}$and $\mathrm{Cl}^{-}$) and ionic imbalances acting on biophysical and/or metabolic components of plant growth (Grattan and Grieve, 1999). When salinity is due to sodium salts, it can lead to the formation of sodic soils when salts 
are leached from the soil profile. Many salt-affected soils are also waterlogged, at least at times, and the interaction between hypoxia and salt has a powerful depressive effect on plant growth (Barrett-Lennard, 2003). In saline conditions, many plants are able to compensate partially low osmotic potential of soil water by building up higher internal solute contents. This is done by absorbing ions from the soil solution and by synthesizing organic osmolytes. Both these reactions reduce the impact of osmotic potential on water availability (Allen et al., 1998).

Several researches (Shani and Dudley, 2001; Gideon et al., 2002; Katerji et al., 2003) have indicated that when saline waters are used for irrigation many attention should be given to minimize root-zone salinity. Others have indicated the need of selection and use of appropriate irrigation systems and practices that will supply just sufficient quantity of water to the root-zone to meet the evaporative demand and minimize salt accumulation in the root-zone (Fisher, 1980; Munns, 2002). Irrigation turn has stated one of the most important factors in crop management when using saline water for irrigation (Pereira et al., 2009). Saline water requires more frequent irrigation than for fresh water because salts in the water and the soil increase the osmotic potential of the soil water, which makes water uptake by the crop roots more difficult. The threshold value above which deleterious effects occur can vary depending on several factors including plant type, soil water regime and climatic condition (Maas, 1986). For example, in rainfed agriculture, soil water can be far below field capacity and the salt concentration under field conditions is several-fold higher than measured at soil saturation water content (Rengasamy, 2002).

In southern Italy, it is a common practice to use saline waters for irrigation. Therefore, often, many field crops are cultivated in soils affected by salinity problems. This factor reduces the quality and yield of these crops as tomato, leaf vegetables and artichoke. In Southern Italy, artichoke represents one of the most important crops with cultivation at about 17,000 ha and over $35 \%$ of national production.

Many trial results indicate the artichoke as a moderately salt tolerant species (Graifenberg et al., 1993; Francois, 1995; Cantore et al., 2004; Bianchimano et al., 2005; Cantore et al., 2007) according to Mass and Hoffman (1977) model, and pointed out negative effects of salinity on absorption and translocation of $\mathrm{Ca}^{++}$that is easily connected to bud atrophy (Francois et al., 1991; Francois, 1995).

The water depletion fraction for water and/or salinity stress in artichoke crop is equal to $45 \%$ of total soil available water (Allen et al., 1998). For this crop are not available literature data showing the optimal water depletion fraction in saline conditions. Therefore, the aim of this work is to evaluate the best watering regime in relation to the salinity.

\section{Materials and methods}

\section{Experimental site: climate and soil characteristics}

The research was carried out during two crop cycles (from July 2007 to May 2009) in open field at the experimental farm E. Pantanell located in Policoro (MT) $\left(40^{\circ} 10^{\prime} 20^{\prime \prime} \mathrm{N}, 16^{\circ} 39^{\prime} 04^{\prime \prime} \mathrm{E}\right)$ in southern Italy. This site is $15 \mathrm{~m}$ above sea level and is characterized by sub-humid climate according to De Martonne classification (Cantore et al., 1987), with average annual rainfall of $560 \mathrm{~mm}$ distributed mainly during autumn and winter, and a maximum temperature reaching in summer more than $40^{\circ} \mathrm{C}$.

The soil is more than $1.2 \mathrm{~m}$ deep and is characterized as loam with sand $(2>\emptyset>0.02 \mathrm{~mm}) 40 \%$, silt $37.1 \%$, clay $(\emptyset<2 \mu) 22.9 \%$; $\mathrm{pH} 7.7$; total $\mathrm{N}$ (Kjeldahl method) $1.67 \mathrm{~g} \mathrm{~kg}^{-1}$, available P205 (Olsen method) 26.7 $\mathrm{mg} \mathrm{kg}{ }^{-1}$, exchangeable $\mathrm{K}_{2} \mathrm{O}$ (ammonium acetate method) $227 \mathrm{mg} \mathrm{kg}^{-1}$, organic matter (Walkley-Black method) $36.4 \mathrm{~g} \mathrm{~kg}^{-1}$, total limestone 15.0 $\mathrm{g} \mathrm{kg}^{-1}$, active limestone $5.0 \mathrm{~g} \mathrm{~kg}^{-1}$; saturate paste extract electrical conductivity (ECe) $0.95 \mathrm{dS} \mathrm{m}^{-1}$, ESP 1.9\%; bulk density $1.25 \mathrm{~kg} \mathrm{dm}^{-3}$; soil moisture at field capacity (measured in situ) $31.5 \%$ and at wilting point $(-1.5 \mathrm{MPa}) 15 \%$ of soil dry weight.

\section{Treatments and cultural practices}

Artichoke (Cýnara cardunculus [L.] subsp. scólymus Hayek) Violetto di Provenza was irrigated with water having three salinity levels: $0.5 \mathrm{dS}$ $\mathrm{m}^{-1}$ i.e. fresh water used as control (S0), and 5 and $10 \mathrm{dS} \mathrm{m}^{-1}$, labelled as $\mathrm{S} 1$ and $\mathrm{S} 2$, respectively, and three water scheduling regimes (irrigating at 20,40 and $60 \%$ of available water depletion, and corresponding to W1, W2 and W3, respectively. S1 and S2 salinity levels were obtained by adding $\mathrm{NaCl}$ to the fresh water. A split plot experimental design with three replicates was established with salinity levels as main factor and the water regimes in the sub-plots of $20 \mathrm{~m} 2$. Irrigation was applied when water lost by evapotranspiration (ETc) reached predetermined levels (W1, W2 and W3) of available water depletion in the soil layer explored by roots, with a watering volume able to restore $100 \%$ of water lost. The crop evapotranspiration (ETc) was calculated by evapotranspirometric method, utilizing daily values of class $A$ pan evaporation, and the crop coefficients of artichoke reported by Boari et al. (2000) and adjusted for saline treatments (Allen et al., 1998).

In mid-July of the first year (2007) ovoli of artichoke were planted in the field in rows $1 \mathrm{~m}$ apart with $1 \mathrm{~m}$ in the row. After the first crop cycle (July 2007-May 2008), artichoke was resumed in mid-July 2008 by abundant irrigation. The irrigation was performed by drip method, with drip lines placed along each row, with in-line emitters located $0.30 \mathrm{~m}$ apart and an emitter flow rate of $4 \mathrm{~L} \mathrm{~h}^{-1}$. Offshoot removal was performed in November of each year keeping the two more vigorous shoots per plant. At pre-plant and pre-resumption time fertilizer was spread (180 and $80 \mathrm{~kg} \mathrm{ha}^{-1}$ of $\mathrm{N}$ and $\mathrm{P}_{2} \mathrm{O}_{5}$ ) and incorporated into the soil. An integrated crop pest management approach was used according the Apulia Regional Law. Moreover, a hand weeding program was followed during the growing periods.

\section{Climatic parameters}

The main climatic parameters were provided by a standard weather station located about $50 \mathrm{~m}$ from the experimental field and equipped with pyranometer (CM 4, Kipp and Zonen, Delft, The Netherlands), thermistor (E001, Tecno.El, Roma, Italy), hygrometer (C-83_N Rotronic, Zurich, Switzerland), anemometer (VT 0805B, SIAP Bologna, Villanova di Castelnaso, B0, Italy), class A pan (NovaLynx Corporation Grass Valley, Auburn, CA, USA), and tipping bucket rain gauge (Tecno.El), for measuring solar radiation, air temperature, relative humidity, wind speed, evaporation and rainfall, respectively. The weather data were collected by the electronic system operated through a data-logger (Kampus, Tecno.El) connected via modem to a PC.

\section{Soil moisture and salinity}

The soil moisture at depth 0-0.6 m was measured every twenty days by gravimetric method in three places per plot, crosswise to the row at 0 - $0.25-0.5 \mathrm{~m}$ from the emitters.

ECe was measured monthly in situ at $0-0.6 \mathrm{~m}$ depth by the EC-probe (Eijkelkamp Agrisearch Equipment) in three places per plot, crosswise to the row at $0-0.25-0.50 \mathrm{~m}$ (from the emitters),. The measures were performed with soil moisture at field capacity (one day after an abundant rainfall or irrigation) (Rhoades and van Schilfgaarde, 1976).

\section{Growth, yield, yield components and quality}

Fifteen and seventeen harvests took place in the December-May period, respectively in the $1^{\text {st }}$ and $2^{\text {nd }}$ crop cycle.

All picked heads were selected into three classes (main secondary 
and heads of successive order - for processing) on which the following observations were done: number and weight of marketable and unmarketable heads (including the atrophic one).

On a sample of 10 marketable heads for each class chosen randomly the following quality traits were measured: edible part percentage (after cutting off the waste bracts) and dry matter (DM) reached (after about 48 hours) in a ventilated oven at $55^{\circ} \mathrm{C}$ of temperature, until a constant weight.

\section{Statistical analysis}

Analysis of variance of the treatment effects on measured traits was performed using the SPSS software package, the differences between means were analyzed with the Student-Newman-Keuls test.

\section{Results and discussion}

\section{Climatic trend}

Rainfall during the 1st crop cycle (July 2007 - May 2008) was irregular and resulted 40\% lower than long-term average (337 against 543 $\mathrm{mm}$ ), with monthly values fluctuating between 0 in August and $80 \mathrm{~mm}$ in October. More than $90 \%$ of the total rainfall occurred in the OctoberFebruary period (Figure 1). Daily minimum temperature (Tmin) ranged between -1.4 and $29.5^{\circ} \mathrm{C}$ and maximum one (Tmax) between 2.5 and $41.5^{\circ} \mathrm{C}$. The lowest Tmin occurred in the middle of February and the highest Tmax at the end of July (Figure 1).

In the 2nd crop cycle (July 2008 - May 2009), rainfall regime resulted irregular, with a total rainfall $(687 \mathrm{~mm}) 15 \%$ higher than long-term average. About $63 \%$ of total rainfall occurred between the middle of November and the beginning of March (Figure 1), Tmin and Tmax ranged between $-0.5 \div 29^{\circ} \mathrm{C}$ and $8.5 \div 40^{\circ} \mathrm{C}$, respectively.

\section{Soil salinity}

During the first crop cycle, ECe of the soil layer from 0 to $0.6 \mathrm{~m}$ depth increased in S1 and S2 treatments as a consequence of salts distributed by irrigation, whereas in the control treatment remained stationary with values ranging around $1 \mathrm{dS} \mathrm{m}^{-1}$ (Figure 2). ECe mean of the whole crop cycle in the three salinity treatments (average of the soil layer from 0 to $0.6 \mathrm{~m}$, three watering regimes and three distances from the emitter) was equal to $1.1,4.3$ and $7.8 \mathrm{dS} \mathrm{m}^{-1}$, respectively for $\mathrm{S} 0, \mathrm{~S} 1$ and S2. The soil ECe raised increasing the distance between 0 to $0.5 \mathrm{~m}$ from the emitters, but no difference was observed between the watering regimes (data not shown).

As a consequence of rainfall and irrigation distribution, ECe raised in the saline treatments until September, decreased in October, and raised progressively afterwards, reaching, at the end of crop cycle, 8.7 and $16.4 \mathrm{dS} \mathrm{m}^{-1}$ in S1 and S2, respectively (Figure 2). In the $2^{\text {nd }}$ crop cycle ECe remained steady around $1 \mathrm{dS} \mathrm{m}^{-1}$ in agreement with the first year. Instead, in saline treatments the ECe trend was different respect to the first crop cycle. At growth restarting ECe was high (7.8 and 15.7 $\mathrm{dS} \mathrm{m}{ }^{-1}$, respectively in S1 and S2), because of salts stored in the soil
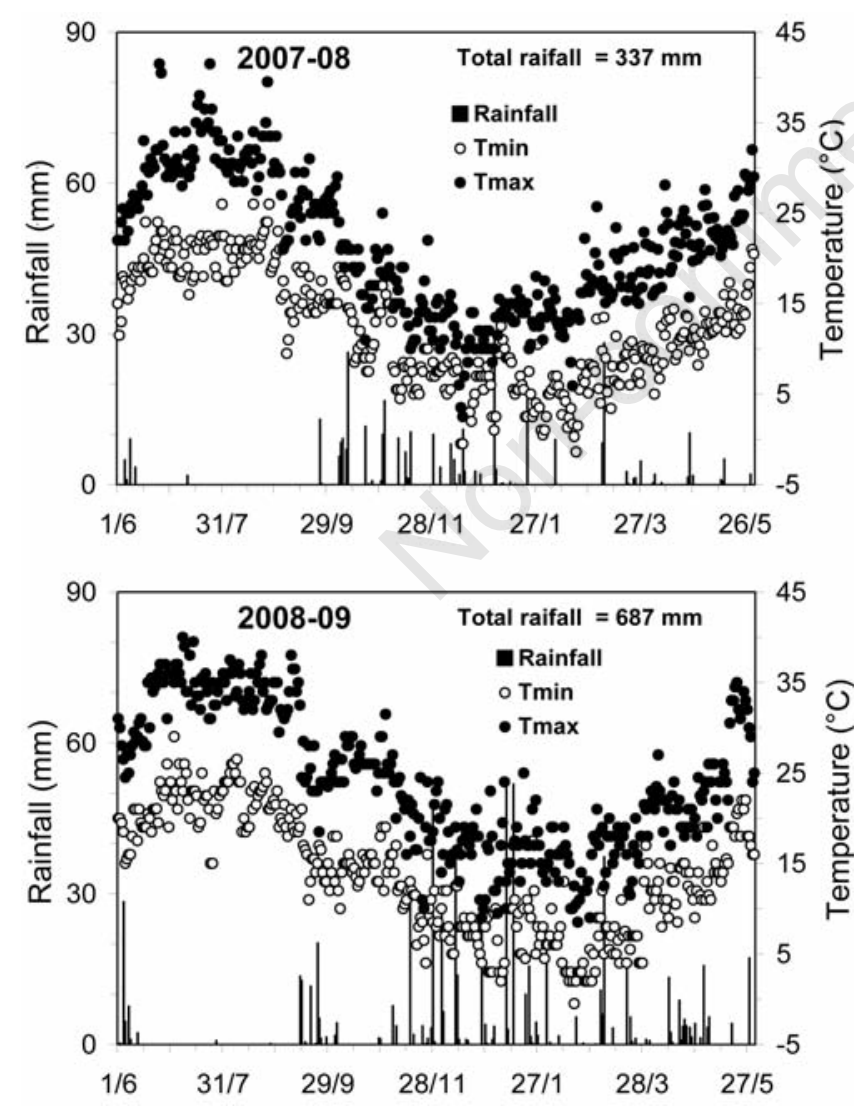

Figure 1. Daily minimum temperature (Tmin), maximum temperature (Tmax) and rainfall during the first (2007-2008) and the second (2008-2009) crop cycle of artichoke.
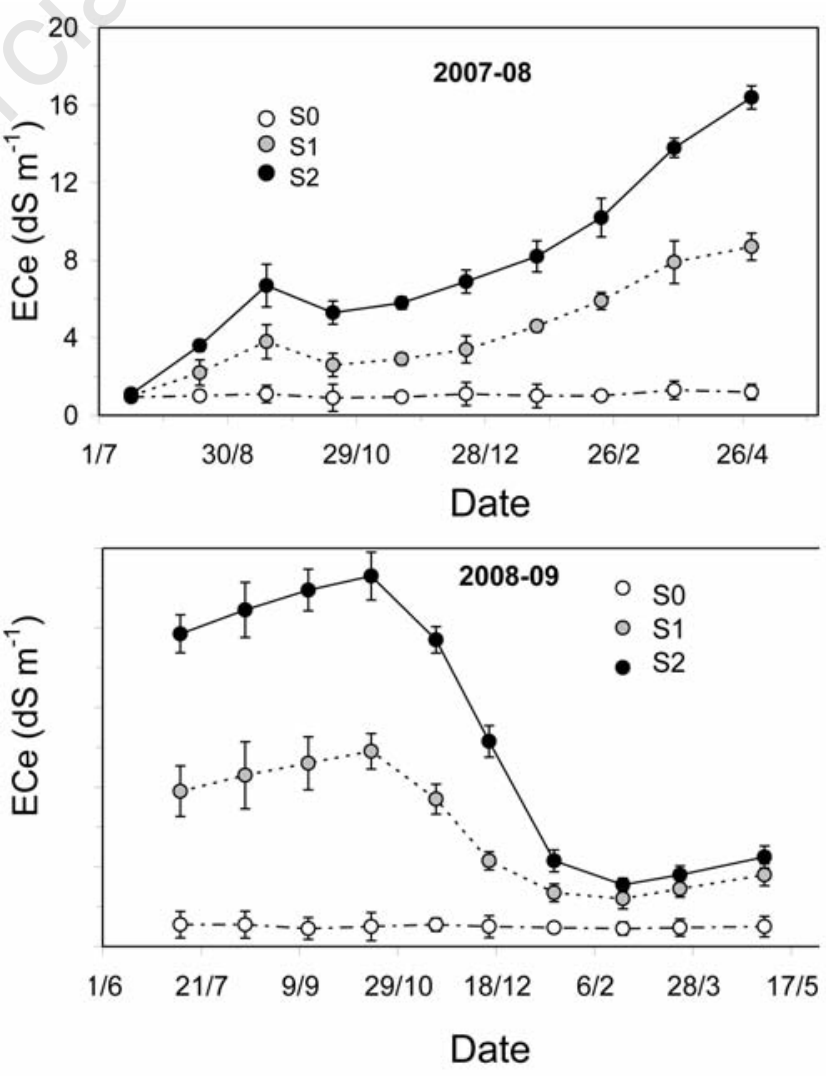

Figure 2. Soil ECe in the three salinity treatments (S0, S1 and S2), of the layer 0-60 cm depth, during the artichoke crop cycle. Each value represents the average between three watering regimes $(\mathrm{W} 1$, W2 and W3), three distances from the emitter $(0,25$ and $50 \mathrm{~cm})$ and three replicates. Vertical bars show $\pm S D$. 
during the former crop cycle. During the summer period ECe increased further, reaching 9.8 (S1) and $18.6 \mathrm{dS} \mathrm{m}^{-1}$ (S2) whereas, in the winter period, dropped progressively until $2.4(\mathrm{~S} 1)$ and $3.1 \mathrm{dS} \mathrm{m}^{-1}(\mathrm{~S} 2)$, as a consequence of leaching promoted by rainfall (Figure 2). ECe mean of the whole crop cycle in the three salinity treatments was equal to 1.0 , 5.9 and $11.0 \mathrm{dS} \mathrm{m}^{-1}$ for $\mathrm{S} 0, \mathrm{~S} 1$ and S2 respectively (Figure 2).

\section{Yield and artichoke heads characteristics}

The marketable yield was slightly different between the years. In the $2^{\text {nd }}$ year, although the heads number was $3 \%$ higher than in the $1^{\text {st }}$ one, the yield was $3 \%$ lower in terms of weight because of $5 \%$ higher mean weight in the $1^{\text {st }}$ year. Within the classes of heads the number of that for processing was $21 \%$ higher in the $2^{\text {nd }}$ year in respect to the $1^{\text {st }}$ one.
The difference between two years probably occurred due to different soil salinity regimes during the crop cycles (Tables 1 and 2).

As a whole, salinity and watering conditions affected marketable yield and artichoke heads characteristics (Tables 1, 2, and 3). As a consequence of the salinity increase from S0 to S2, the total heads yield decreased in terms of number and weight from 125,100 to $94,700 \mathrm{n} \mathrm{ha}^{-1}$ and from 12.9 to $8.8 \mathrm{Mg} \mathrm{ha}^{-1}$, respectively. The higher reduction in terms of weight is due to $10 \%$ reduction of head mean weight. These results are in agreement with those of other authors that reported the negative effect of salinity on artichoke head yield mainly in terms of weight and number (Cantore et al., 2004; Bianchimano et al., 2005).

Higher tolerance observed for number of heads in respect to their weight is of great importance for the Italian market since the arti-

Table 1. Effect of year, salinity and irrigation regime on artichoke marketable yield.

\begin{tabular}{|c|c|c|c|c|c|c|c|c|}
\hline \multirow[t]{2}{*}{ Treatments } & \multicolumn{4}{|c|}{ Heads $\left(\mathrm{n} . \mathrm{ha}^{-1}\right) \times 10^{3}$} & \multicolumn{4}{|c|}{ Heads $\left(\mathrm{Mg} \mathrm{ha}^{-1}\right)$} \\
\hline & Main & Secondary & For processing & Total & Main & Secondary & For processing & Total \\
\hline \multicolumn{9}{|l|}{ Years } \\
\hline 2007-08 & 19.0 & 69.3 & $22.0^{b}$ & 110.3 & 2.7 & 7.3 & 1.1 & 11.1 \\
\hline 2008-09 & 19.6 & 67.7 & $26.7^{\mathrm{a}}$ & 114.0 & 2.7 & 6.9 & 1.2 & 10.8 \\
\hline \multicolumn{9}{|l|}{ Salinity } \\
\hline So & $21.0^{\mathrm{a}}$ & $79.0^{\mathrm{a}}$ & 25.1 & $125.1^{\mathrm{a}}$ & $3.0^{\mathrm{a}}$ & $8.7^{\text {a }}$ & 1.2 & $12.9^{\mathrm{a}}$ \\
\hline S1 & $18.9^{\mathrm{b}}$ & $73.9^{b}$ & 23.9 & $116.7^{\mathrm{b}}$ & $2.7^{\mathrm{ab}}$ & $7.3^{b}$ & 1.1 & $11.1^{\mathrm{b}}$ \\
\hline S2 & $18.0^{\mathrm{b}}$ & $52.6^{c}$ & 24.1 & $94.7^{\mathrm{c}}$ & $2.4^{b}$ & $5.3^{c}$ & 1.1 & $8.8^{c}$ \\
\hline \multicolumn{9}{|c|}{ Irrigation regime } \\
\hline W1 & 19.8 & $73.4^{\mathrm{a}}$ & 24.5 & $117.7^{\mathrm{a}}$ & 2.8 & $7.8^{\mathrm{a}}$ & 1.2 & $11.8^{a}$ \\
\hline W2 & 19.4 & $70.5^{a}$ & 23.1 & $113.0 \mathrm{ab}$ & 2.7 & $7.2^{a b}$ & 1.1 & $11.0 \mathrm{ab}$ \\
\hline W3 & 18.8 & $61.6^{b}$ & 25.5 & $105.9^{\mathrm{b}}$ & 2.6 & $6.3^{\mathrm{b}}$ & 1.0 & $10.0^{\mathrm{b}}$ \\
\hline \multicolumn{9}{|l|}{ Significance } \\
\hline $\mathrm{Y}$ & ns & ns & $*$ & ns & ns & ns & ns & ns \\
\hline S & $*$ & $* *$ & ns & * & $*$ & $* *$ & ns & $* *$ \\
\hline IRns & $*$ & ns & $*$ & ) & ns & $*$ & ns & $*$ \\
\hline S.Y & $*$ & ns & ns & ns & ns & ns & ns & ns \\
\hline IR.Y & ns & ns & ns & ns & ns & ns & ns & ns \\
\hline S.IR & $*$ & $*$ & $*$ & $*$ & $*$ & $* *$ & ns & $*$ \\
\hline Y.S.IR & ns & ns & ns & ns & ns & ns & ns & ns \\
\hline
\end{tabular}

$\mathrm{Y}$, year; S, salinity; IR, irrigation regime; a, bvalues followed by different letters within columns are significantly different by $\mathrm{SNK}$ test, $\mathrm{P}<0.05 ;$ ns, $\mathrm{F}$ test not significant; ${ }^{*} \mathrm{~F}$ test significant at $\mathrm{P}<0.05$ and $* * \mathrm{P}<0.01$.

Table 2. Effect of year, salinity and irrigation regime on heads mean weight and atrophic heads yield.

\begin{tabular}{|c|c|c|c|c|c|c|}
\hline \multirow[t]{2}{*}{ Treatments } & \multicolumn{3}{|c|}{ Heads mean weight (g) } & \multicolumn{3}{|c|}{ Heads atrophy $\left(\mathrm{n} . \mathrm{ha}^{-1}\right) \times 10^{3}$} \\
\hline & Main & Secondary & For processing & Main & Secondary & For processing \\
\hline \multicolumn{7}{|l|}{ Years } \\
\hline 2007-08 & $142.9^{\text {a }}$ & 104.0 & $49.3^{\mathrm{a}}$ & $0.0^{\mathrm{b}}$ & 0.0 & 0.0 \\
\hline 2008-09 & $137.3^{\mathrm{b}}$ & 102.0 & $44.0^{b}$ & $0.8^{\mathrm{a}}$ & 0.2 & 0.0 \\
\hline \multicolumn{7}{|l|}{ Salinity } \\
\hline S0 & $143.4^{\mathrm{a}}$ & $110.4^{\mathrm{a}}$ & 47.1 & $0.0^{\mathrm{c}}$ & 0.0 & 0.0 \\
\hline S1 & $142.4^{\mathrm{a}}$ & $99.4^{\mathrm{b}}$ & 46.0 & $0.4^{\mathrm{b}}$ & 0.0 & 0.0 \\
\hline $\mathrm{S} 2$ & $134.5^{\mathrm{b}}$ & $99.1^{\mathrm{b}}$ & 46.8 & $1.2^{\text {a }}$ & 0.3 & 0.0 \\
\hline \multicolumn{7}{|c|}{ Irrigation regime } \\
\hline W1 & 141.0 & $105.3^{\mathrm{a}}$ & 47.2 & 0.4 & 0.0 & 0.0 \\
\hline W2 & 139.7 & $101.7^{b}$ & 45.7 & 0.4 & 0.1 & 0.0 \\
\hline W3 & 139.6 & 101.9 b & 47.0 & 0.4 & 0.2 & 0.0 \\
\hline \multicolumn{7}{|l|}{ Significance } \\
\hline $\mathrm{Y}$ & $*$ & ns & $*$ & $*$ & ns & ns \\
\hline $\mathrm{S}$ & $*$ & $*$ & ns & $*$ & ns & ns \\
\hline IRns & $*$ & ns & & ns & ns & ns \\
\hline S.Y & ns & ns & ns & $*$ & ns & ns \\
\hline IR.Y & ns & ns & ns & ns & ns & ns \\
\hline S.IR & ns & ns & ns & ns & ns & ns \\
\hline Y.S.IR & ns & ns & ns & ns & ns & ns \\
\hline
\end{tabular}

Y, year; S, salinity; IR, irrigation regime; a,b,c values followed by different letters within columns are significantly different by SNK test, $\mathrm{P}<0.05 ;$ ns, $\mathrm{F}$ test not significant; ${ }^{*} \mathrm{~F}$ test significant at $\mathrm{P}<0.05$ and $* * \mathrm{P}<0.01$. 
chokes are sold by heads number instead of weight (Cantore et al., 2004). The salinity levels influenced the main and secondary heads: i) the main heads yield number and weight by 12 and $15 \%$, respectively, and ii) the secondary heads yield number and weight by 33 and $39 \%$, respectively. Moreover, some differences in salinity effect on artichoke yield was observed for the two years. In particular, the main heads yield number decreased with the salinity increase only in the 2nd year. This could be explained by the fact that the main heads are the 1st one produced, and their differentiation had taken place when the soil salinity was low in the $1^{\text {st }}$ year and very high in the $2^{\text {nd }}$ one. The rate of yield reduction in relation to the soil salinity is similar to the results reported in literature indicating artichoke as a moderately salt tolerant species (Graifenberg et al., 1993; Francois, 1995; Bianchimano et al., 2005; Cantore et al., 2007) and in accordance to Mass and Hoffman (1977) model. The watering regime, as average of the salinity levels did not affect total heads yield in W1 and W2 (on average 115,350 n ha and $11.4 \mathrm{Mg} \mathrm{ha}^{-1}$ ), whereas in W3 it was reduced by 8.2 and $12.3 \%$ as heads number and weight, respectively (Table 1). The effect of watering regime occurred only for the secondary heads yield for which was observed a reduction equal to $3 \%$ of mean weight.

Moreover, the effect of different watering regimes is related to the variations in salinity level (Figure 3). Salinity tolerance decreased irrigating less frequently and watering regimes did not affect heads number and weight yield in $\mathrm{S} 0$. In S1, the best watering regimes were both W1 and W2, whereas in S2 the best one was W1.

Nevertheless, in terms of total heads number yield, for S1 was observed a decrease in W3 (-6.8\%), while for S2 a decrease occurred in W2 $(-11.2 \%)$ and in W3 (-23.3\%). In terms of heads weight yield, the reduction occurred in W2 (-9.8 and -11.9\%) and W3 (-16.4 and -25.7\%) for S1 and S2 salinity levels, respectively

In the second year was observed high incidence of head atrophy in the main heads with high salinity levels. This effect occurred for the negative influence of salinity on absorption and translocation of $\mathrm{Ca}^{++}$ that is easily connected to head atrophy (Francois et al., 1991; Francois, 1995), mainly at beginning of vegetative cycle, when high air temperature, low air humidity and the high evaporative demand contribute to a reduction of $\mathrm{Ca}^{++}$translocation into the artichoke heads.

Salinity increased dry matter of edible part of heads, but that did not occurred for the main heads produced in the 1st year when the soil salinity was still low. Moreover, salinity reduced the percentage of the edible part of heads.
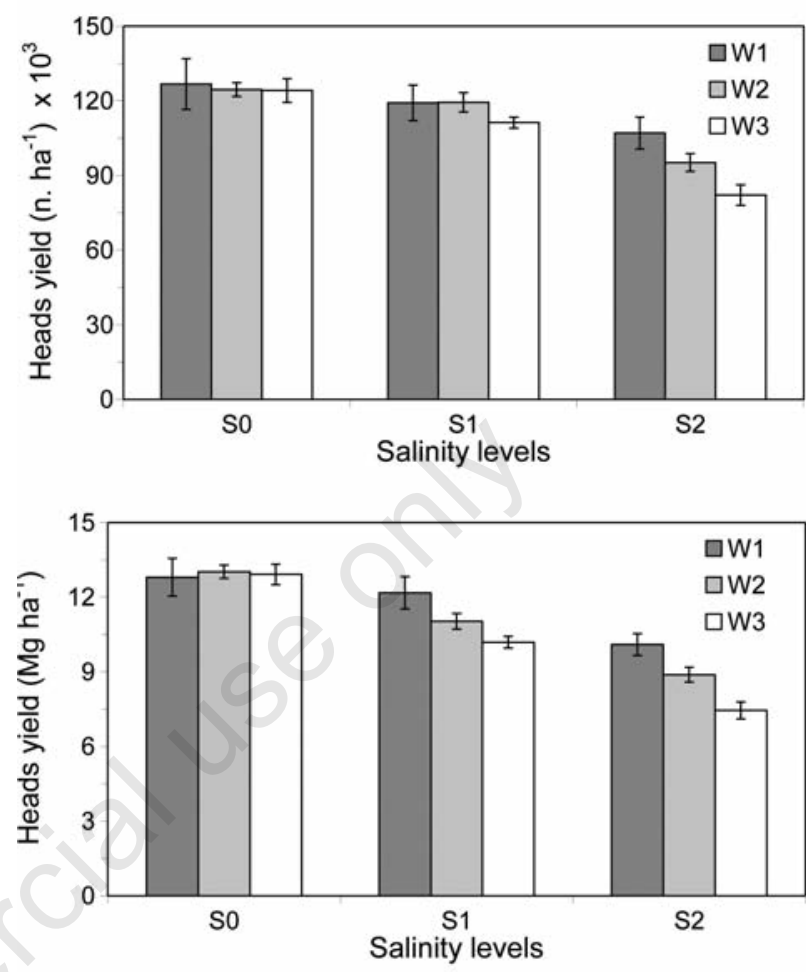

Figure 3. Heads yield per plant and per hectare: interaction between salinity levels and watering regimes (W1, W2 and W3). Vertical bars indicate $\pm S D$.

Table 3. Effect of year, salinity and irrigation regime on heads dry matter and edible part percentage.

\begin{tabular}{|c|c|c|c|c|c|c|}
\hline \multirow[t]{2}{*}{ Treatments } & \multicolumn{3}{|c|}{ DM $\left(\mathrm{g} \mathrm{kg}^{-1} \mathrm{fw}\right)$} & \multicolumn{3}{|c|}{ Heads edible part (\%) } \\
\hline & Main & Secondary & For processing & Main & Secondary & For processing \\
\hline \multicolumn{7}{|l|}{ Years } \\
\hline 2007-08 & 171.1 & 174.4 & 181.1 & 33.8 & 34.4 & 35.0 \\
\hline 2008-09 & 175.5 & 176.6 & 176.6 & 33.6 & 34.0 & 35.4 \\
\hline \multicolumn{7}{|l|}{ Salinity } \\
\hline SO & $159.9^{c}$ & $161.1^{\mathrm{c}}$ & $164.4^{\mathrm{c}}$ & $34.5^{\mathrm{a}}$ & $35.2^{\mathrm{a}}$ & $36.0^{\mathrm{a}}$ \\
\hline S1 & $170.0^{b}$ & $172.2^{\mathrm{b}}$ & $176.6^{\mathrm{b}}$ & $34.0^{\mathrm{a}}$ & $34.5^{a b}$ & $35.2^{a b}$ \\
\hline S2 & $189.9^{\text {a }}$ & $192.2^{\mathrm{a}}$ & $198.8^{a}$ & $32.2^{b}$ & $33.0^{\mathrm{b}}$ & $34.4^{\mathrm{b}}$ \\
\hline \multicolumn{7}{|c|}{ Irrigation regime } \\
\hline W1 & 172.3 & 175.5 & 179.9 & 33.7 & 34.5 & 35.4 \\
\hline W2 & 174.4 & 177.7 & 182.2 & 33.5 & 34.2 & 35.0 \\
\hline W3 & 173.3 & 173.3 & 177.7 & 34.0 & 33.8 & 35.2 \\
\hline \multicolumn{7}{|l|}{ Significance } \\
\hline $\mathrm{Y}$ & ns & ns & ns & ns & ns & ns \\
\hline S & $* *$ & $* *$ & $* *$ & $*$ & $*$ & $*$ \\
\hline IRns & ns & ns & ns & ns & ns & \\
\hline S.Y & $*$ & ns & ns & ns & ns & ns \\
\hline IR.Y & ns & ns & ns & ns & ns & ns \\
\hline S.IR & ns & ns & ns & ns & ns & ns \\
\hline Y.S.IR & ns & ns & ns & ns & ns & ns \\
\hline
\end{tabular}

Y, year; S, salinity; IR, irrigation regime; a,b,cyalues followed by different letters within columns are significantly different by $\mathrm{SNK}$ test, $\mathrm{P}<0.05 ;$ ns, $\mathrm{F}$ test not significant; ${ }^{*} \mathrm{~F}$ test significant at $\mathrm{P}<0.05$ and ${ }^{* *} \mathrm{P}<0.01$. 


\section{Conclusions}

The results of this research confirm that the osmotic stress due to the soil salinity interferes with water availability and that optimal water depletion fraction in saline condition decreases and depends also on the crop yield characteristics (Allen et al., 1998). These results demonstrate that artichoke irrigated with saline water needs watering more frequently, mainly to preserve heads weight yield.

To preserve heads number and weight yield in the conditions of moderate salinity (S1), the maximum water depletion fractions were 40 and $20 \%$ of total soil available water when irrigating by drip method. Nonetheless, with high salinity (S2), maximum water depletion fraction was $20 \%$ both for heads number and for weight yield. The lower value (45\%) of water depletion fraction for no water and/or salinity stress, reported in literature (Allen et al., 1998), respect to the value of $60 \%$, resulted in the control (S0) of this trial, can be ascribed to the different irrigation method and environmental conditions.

\section{References}

Allen RG, Pereira LS, Raes D, Smith M, 1998. Crop evapotranspiration. FAO Irrigation and Drainage Paper no. 56. FAO Publ., Roma, Italy.

Barret-Lennard G, 2003. The interaction between waterlogging and salinity in higher plants: causes, consequences and implications. Plant Soil 253:35-54.

Bianchimano V, Bianco VV, Cantore V, Boari F, 2005. Response of artichoke to salinity. Acta Hortic. 681:143-150.

Boari F, Cantore V, De Palma E, Rubino P, 2000. Evapotranspiration trend in seed propagated artichoke, Cynara cardunculus L. var. scolymus (L.) Fiori, in southern Italy. Acta Hortic. 537:511-518.

Cantore V, Boari F, Bianchimano V, Bianco VV, 2004. Effect of soil salinity on artichoke (Cynara cardunculus [L.] subsp. scolymus Hayek). Acta Hortic. 660:311-316.

Cantore V, Boari F, Pace B, De Palma E, 2007. Effects of salinity on new artichoke cultivars. Acta Hortic. 730:187-192.

Cantore V, Iovino F, Pontecorvo G, 1987. Aspetti climatici e zone fitoclimatiche della Basilicata. C.N.R. IEIF-Cosenza, Grafiche Badiali s.n.c. Ed., Arezzo, Italy.

Cotecchia V, Polemio M, 1997. Monitoraggio idrogeologico continuo per salvaguardare le acque sotterranee pugliesi. Dimensione Ricerca 2:11-15.

Fisher RA, 1980. Influence of water stress on crop yield in semiarid regions. In: N.C. Turner and P.J. Kramer (eds.) Crop Water Requirements. INRA Publ., Paris, France, pp 221-234.

Francois LE, Donovan TJ, Maas EV, 1991. Calcium deficiency of Artichoke buds in relation to salinity. Hortic. Sci. 26:549-553.

Francois LE, 1995. Salinity effects on bud yield and vegetative growth of artichoke (Cynara scolymus L.). Hortscience 30:69-71.
Gideon 0, DeMalach Y, Gillerman L, David I, Lurie S, 2002. Effect of water salinity and irrigation technology on yield and quality of pears. Biosyst. Eng. 81:237-247.

Graifenberg A, Lipucci di Paola M, Giustiniani L, Temperini 0, 1993. Yield and growth of globe artichoke under saline-sodic conditions. Hortscience 28:791-793.

Grattan SR, Grieve CM, 1999. Salinity-mineral nutrient relations horticultural crops. Sci. Hortic.-Amsterdam 78:127-157.

Hillel D, 2005. Soil salinity: historical and contemporary perspectives. pp 235-240 in Proc. Int. Salinity Forum, Riverside, CA, USA.

Jacobsen T, Adams RM, 1958. Salt and silt in ancient Mesopotamian agriculture. Science 128:1251-1258.

Katerji N, van Hoorn JW, Hamdy A, Mastrorilli M, 2003. Salinity effect on crop development and yield analysis of salt tolerance according to several classification methods. Agric. Water Manage. 62:37-66.

Maas EV, 1986. Salt tolerance of plants. Appl. Agric. Res. 1:12-26.

Maas EV, Hoffman GJ, 1977. Crop salt tolerance - current assessment. J. Irr. and Drain. Div.-ASCE 103:115-134.

Martinez-Beltran J, Manzur CL, 2005. Overview of salinity problems in the world and FAO strategies to address the problem. pp 311-313 in Proc. Int. Salinity Forum, Riverside, CA, USA.

Munns R, 2002. Comparative physiology of salt and water stress. Plant Cell Environ. 25:239-250.

Munns R, 2005. Genes and salt tolerance: bringing them together. New Phytol. 167:645-663.

Pereira LS, Cordery I, Iacovos I, 2009. Coping with water scarcity. Springer Ed., Dordrecht, The Netherlands.

Polemio M, Limoni PP, 2001. L'evoluzione dell'inquinamento salino delle acque sotterranee della Murgia e del Salento. Mem. Soc. Geol. It. $56: 327-331$.

Rapti-Caputo D, 2010. Influence of climatic changes and human activities on the salinization process of coastal aquifer systems. Ital. J. Agron. 5(Suppl.3):67-79.

Rengasamy P, 2002. Transient salinity and subsoil constraints to dryland farming in Australian sodic soils: an overview. Aust. J. Exp. Agr. 42:351-361.

Rengasamy P, 2006. World salinization with emphasis on Australia. J. Exp. Bot. 57:1017-1023.

Rhoades JD, 1987. Use of saline water for irrigation. Water Qual. Bull. $12: 14-20$

Rhoades JD, van Schilfgaarde J, 1976. An electrical conductivity probe for determining soil salinity. Soil Sci. Soc. Am. J. 40:647-651.

Rhoades JD, Kandiah A, Mashali AM, 1992. The use of saline waters for crop production. FAO Irrigation and Drainage Paper No. 48. FAO Publ., Roma, Italy.

Shani U, Dudley LM, 2001. Field studies of crop response to water and salt stress. Soil Sci. Soc. Am. J. 65:1522-1528.

United States Salinity Laboratory Staff, 1954. Diagnosis and improvement of saline and alkali soils. US Department of Agriculture, Agricultural Handbook No. 60. US Government Printer, Washington, DC, USA. 